\title{
The Effect of Service Quality through the Patients Satisfaction to Word of Mouth at Praktik Mandiri Bidan Maria Surabaya
}

\author{
Ulul Abror , I Nyoman Sudapet, Hamzah Denny Subagyo, \& Joko Suyono \\ Faculty of Economics and Business, Narotama University, Surabaya, Indonesia
}

\begin{abstract}
The aim of this study: (1) to analyze the effect of service quality on Patient Satisfaction, (2) to analyze the effect of service quality on Word of Mouth, (3) to analyze patient satisfaction with Word of Mouth. This research is quantitative research. Population and sample distributed were 252 respondents. Data collection techniques using a questionnaire. Analysis of the data used is Convergent Validity, Discriminant Validity, Reliability and Average Variance Extracted (AVE). The results showed that the effect of the Service Quality variable (X1) on patient satisfaction (Y1) was significant at 0,000 and Service Quality (X1) is significant with variable Word of Mouth (Y2) of 0.002 which means medium. Based on the correlation for the Patient Satisfaction variable (Y1) for Word of Mouth (Y2) of 0,000 which means strong. The results of this study indicate that, quality of service, has a significant influence on patient satisfaction, which leads to Word of Mouth patients. While patient satisfaction has no significant effect on Word of Mouth patients.
\end{abstract}

Keywords: Service quality; Patient satisfaction; Word of Mouth.

\section{Introduction}

In the world of health, there are now quite a number of hospitals that have been established, especially in the midwife's independent practice, both in the village and in the city, thus competition in the health world is also increasingly increasing, therefore to improve Word of Mouth from its practice, then an independent practice of the maternity home must pay attention to several factors that can affect Word of Mouth from patients, so patients can inform and set their goals in choosing an independent midwife practice to be the goal still when needing treatment or maternity, among others, is Quality of service, Wirtz (2011) which states that Service is an economic activity offered by one party to another. Often time-based, the performance of subordinates desired to recipients, objects or other assets is the responsibility of the buyer.

In this increasingly fierce business competition, entrepreneurs must be able to monitor every development and change in consumer behavior in deciding to buy a product or service. So that it can anticipate its efforts in improving its marketing strategy. Because in essence the purpose of marketing is to know and understand the nature or behavior of consumers well so that the product or service offered can be sold and consumers are satisfied with the product or service produced.

To be able to survive in this increasingly fierce competition entrepreneurs are required to be able to adapt to the needs and desires of customers. Companies also have to learn that the desires and needs of current and future customers by continuing to develop service quality is one way to get Word of Mouth from patients through customer satisfaction. Therefore it is important for entrepreneurs to know consumer behavior, so companies can take advantage of the opportunities they have and are supported by developing technology. This is a business phenomenon and problems that need attention, considering that customer satisfaction is an important factor in the business process, so the

\footnotetext{
* Corresponding author.

E-mail address: ululabror5@gmail.com (Ulul Abror)
} 
Mandiri Practice of Midwife Maria Surabaya can further develop its service system, so that it can further increase patient satisfaction and be able to add Word of Mouth to patients.

\section{Research Objectives}

Objective of this study include :

1. To analyze the effect of service quality on Patient Satisfaction

2. To analyze the effect of service quality on Word of Mouth

3. To analyze patient satisfaction with Word of Mouth

\section{Literature Review}

\subsection{Marketing}

The main task of management according to Ardiansyah \& Winarningsih (2013) there is continuous planning, implementation and supervision. The planning task consists of looking for interesting opportunities and developed into a marketing strategy that is compiled, it requires the readiness of company organization and implementation. Self-management is needed so that the implementation of the marketing strategy can be carried out properly.

Definition of marketing according to Kotler and Keller (2009) is a social process where individuals and groups obtain what is needed and desired by creating, offering and freely exchanging valuable products and services with others. While Assauri (2010) means marketing as a human activity that is directed to fulfill and satisfy and desire through an exchange process.

\subsection{Consumer Behavior}

Understanding consumer behavior according to Solomon \& Tjiptono (2014) is a process that occurs when individuals or groups choose, buy, use, or stop using services, ideas, or experiences to satisfy certain needs and desires.

The American Marketing Associaton in Setiadi (2013) defines consumer behavior as a dynamic interaction between affection and cognition, behavior, and environment where humans carry out exchange activities in their lives. While consumer behavior according to Engel et al. In Mangkunegara (2009: 3) it is defined as the actions of individuals who are directly involved in efforts to obtain and use economic service goods including the decision-making process that precedes and determines these actions.

\subsection{Service Quality}

Tjiptono \& Sunyoto (2012) say that quality is: "a dynamic condition related to products, services, people, processes, and environments that meet or exceed expectations." The indicators of Quality of Service according to Zeithhaml, Parauraman \& Berry (in Hardianyah 2011: 46) are Tangible (tangible), Reliability (reliability), Responsive (responsiveness), Assurance (guarantee), and also Empathy (empathy). Services by Tangible (tangible), Reliabelity (reliability), Responsiveiness (responsiveness), assurance (assurance), and Empathy (empathy).

\subsection{Patient Satisfaction}

Kotler \& Keller (2012) say that customer satisfaction is the level of one's feelings after comparing performance or the results that he feels compared to his expectations. If the performance is below expectations, the customer is not satisfied. If the performance meets expectations, the customer is satisfied, while according to (Lovelock \& Wirtz, 2011) Satisfaction is an attitude that is decided based on the experience gained.

\subsection{Word of Mouth}

Suprapti (2010) suggests that communication is transmitted or Word of Mouth is personal communication between 
two individuals or more, for example between customers or between members of a group. Word of Mouth obtained by customers through people who are trusted like experts, friends, family tend to be accepted faster. In addition to Word of Mouth can also be used as a reference because service customers are usually difficult to evaluate services that have not been purchased or have not been felt by themselves. According to Sernovitz (2009), Word of Mouth is a conversation that naturally occurs between people. Word of Mouth is the talk of genuine consumers.

\subsection{Previous Research}

(1) Pangandaheng, 2013 concerning the influence of service quality and company image on customer satisfaction and its impact on customer loyalty at PT. Hadji kalla palu, The number of samples in this study were 150 respondents. The sampling technique was purposive sampling where deliberate sampling was in accordance with the required sample requirements (Kuncoro, 2003). The results showed that service quality had a positive and significant effect on the image of PT. Hadji Kalla Palu. Service quality does not significantly influence customer satisfaction, because Pvalue $=0.192>0.05$. Citra PT. Hadji Kalla Palu has a positive and significant effect on customer satisfaction. Customer satisfaction has a positive and significant effect on customer loyalty.

(2) Anita, Ni Luh Nyoman Y; Rahanatha, 2018 about the effect of service quality on wom through satisfaction at pt. Means of Goddess Courier, the samples taken were 130 respondents using purposive sampling technique. Data collection is done through the distribution of questionnaires. The analytical method used is the Structural Equation Model (SEM). The results of the study show that directly or indirectly the quality of service has an effect on Word of Mouth through customer satisfaction at PT. Means of Dewata Courier Denpasar.

(3) Sholeha, Djaja, \& Widodo, 2018 Research entitled Influence of Service Quality on Customer Satisfaction AHASS Sumber Jaya Maha Sakti Rogojampi Subdistrict, Banyuwangi Regency, the population taken purposively was 90 respondents. The results of the regression line effectiveness analysis (R2) are $79 \%$. This shows that the percentage effect of service quality on customer satisfaction in AHASS Sumber Jaya Maha Sakti, Rogojampi District, Banyuwangi Regency is $79 \%$. Based on the results of these studies it can be concluded that service quality has a significant influence on customer satisfaction in AHASS Sumber Jaya Maha Sakti, Rogojampi District, Banyuwangi Regency.

\subsection{Hypotheses}

The formulated hypothesis is:

H1: Service Quality is thought to simultaneously have a significant effect on Patient Satisfaction.

H2: Service Quality allegedly simultaneously has a significant effect on Word of Mouth.

H3: patient satisfaction is thought to simultaneously have a significant effect on Word of Mouth.

\section{Methods}

\subsection{Type of Research This}

Tpe of research uses a quantitative approach to examine specific populations or samples, sampling techniques are generally done randomly, data collection uses research instruments, quantitative / statistical analysis with the aim of testing what has been determined. (Sugiyono 2010).

\subsection{Location and Time of Research}

This research was carried out at the site of the independent practice of midwife Maria Jl. Bibis tama 25, Balongsari, Tandes, Surabaya. Therefore, if there are branches found elsewhere, it cannot be connected in this study. The time of this study was carried out for 1 month around May - June 2019. 


\subsection{Popolation and Samples}

Population is the sum of all objects (units / individuals) whose characteristics are to be expected (Sunyoto, Wenehenubun, and Sutanto 2013). The population in this study were patients in the practice of independent maternity midwife mother's house Jl. Bibis tama 25, Balongsari, Tandes, Surabaya. Samples are a portion of the population whose characteristics are to be studied and considered to represent the entire population (Sunyoto et al. 2013). With sampling and calculated using Slovin formula, the sample used in this study amounted to 252 respondents.

\subsection{Analysis Methods}

1) Data Analysis

In this study researchers used data analysis techniques PLS

2) Structural Model (Inner Model)

Ghozali (2015) inner model which is sometimes also called (inner relations, structural model, and substantive theory) describes the relationship between latent variables based on subtantive theory.

3) Measurement Model (Outer Model)

Ghozali (2015) The outer model shows that each indicator block is related to its latent variables.

4) Weight Relations

Ghozali (2015) Outer and Inner models provide specifications followed in PLS algorithm estimation.

5) Evaluation of Sturctural Models (Inner Model)

Structural models were evacuated with PLS. By using R-Square for endogenous (dependent) latent variables. The interpretation is the same as the interpretation in OLS regression. Changes in the value of R-Squares can be used to assess the effect of exogenous latent variables (independent) on endogenous variables (dependent) whether they have substantive effects.

6) Evaluation of Reflexive Indikator Measurement Model (Outer Model)

According to Ghozali \& Aprilia (2016) Convergent validity of the measurement model with a reflective indicator is assessed based on the value of loading factors of each indicator forming a latent construct. A construct is said to have good convergent validity if the loading factor is more than 0.70 and is significant. But for researchers in the early stages of developing a measurement scale, the loading values of 0.5 to 0.6 are considered sufficient. Discriminant validity measurement models with reflective indicators are assessed by comparing the square root value of average variance extracted (AVE) of each latent construct with the correlation between constructs related to other constructs in the model. If the AVE square root value of each construct is greater than the correlation value between constructs and other constructs in the model, then it has good discriminant validity.

\section{7) Quality Indexs}

PLS path modeling can also identify global optimization criteria to find out the goodness of fit of the same model as CB-SEM. For PLS path modeling provides three different fit indexes, namely communaly index, redundancy index, and goodness of fit (GoF) index.

\section{Result and Discussions}

\subsection{Convergent Validity}

Results of processing by using SmartPLS can be seen in Table 1. The value of the outer model or correlation between constructs and latent variables has met convergence validity because the value of the loading factor in the table above is not below the limit of the loading factor of 0.50 . 
Table 1. Outer Loadings (Measurement Model)

\begin{tabular}{cccc}
\hline & $\mathbf{X 1}$ & Y1 & Y2 \\
\hline $\mathbf{X 1 . 1}$ & 0.815 & & \\
$\mathbf{X 1 . 2}$ & 0.823 & & \\
$\mathbf{X 1 . 3}$ & 0.856 & & \\
$\mathbf{X 1 . 4}$ & 0.833 & & \\
$\mathbf{X 1 . 5}$ & 0.87 & & \\
Y1.1 & & 0.717 & \\
Y1.2 & & 0.77 & \\
Y1.3 & & 0.798 & \\
Y1.4 & & 0.82 & \\
Y2.1 & & & 0.741 \\
Y2.2 & & & 0.857 \\
Y2.3 & & & 0.875 \\
\hline
\end{tabular}

\subsection{Discriminant Validity}

Discriminant validity is done to ensure that each concept of each latent variable is different from the other variables. The model has good discriminant validity if each loading value of each indicator of a latent variable has the highest loading value with other loading values for other latent variables. Discriminant validity testing results obtained as table 2 .

Table 2. Value of Discriminant Validity (Cross Loading)

\begin{tabular}{lccc}
\hline & $\begin{array}{c}\text { X1 (Service } \\
\text { Quality) }\end{array}$ & $\begin{array}{c}\text { Y1 (Patients } \\
\text { Satisfaction) }\end{array}$ & $\begin{array}{c}\text { Y2 (Word of } \\
\text { Mouth) }\end{array}$ \\
\hline X1.1 & $\mathbf{0 . 8 1 5}$ & 0.501 & 0.468 \\
X1.2 & $\mathbf{0 . 8 2 3}$ & 0.426 & 0.312 \\
X1.3 & $\mathbf{0 . 8 5 6}$ & 0.535 & 0.357 \\
X1.4 & $\mathbf{0 . 8 3 3}$ & 0.504 & 0.357 \\
X1.5 & $\mathbf{0 . 8 7}$ & 0.581 & 0.472 \\
Y1.1 & 0.333 & $\mathbf{0 . 7 1 7}$ & 0.383 \\
Y1.2 & 0.371 & $\mathbf{0 . 7 7}$ & 0.418 \\
Y1.3 & 0.53 & $\mathbf{0 . 7 9 8}$ & 0.457 \\
Y1.4 & 0.607 & $\mathbf{0 . 8 2}$ & 0.481 \\
Y2.1 & 0.284 & 0.429 & $\mathbf{0 . 7 4 1}$ \\
Y2.2 & 0.408 & 0.463 & $\mathbf{0 . 8 5 7}$ \\
Y2.3 & 0.469 & 0.502 & $\mathbf{0 . 8 7 5}$ \\
\hline
\end{tabular}

From Table 2 can be seen that the value of the loading factor for each indicator of each latent variable has the highest 
loading factor value if it is associated with other latent variables. This means that every latent variable has good discriminant validity.

\subsection{Evaluating Reliability and Average Variance Extracted (AVE)}

Validity and reliability criteria can also be seen from the reliability value of a construct and the value of Average Variance Extracted (AVE) of each construct. Constructions are said to have high reliability if the value is 0.70 and AVE is above 0.50. In table 4.9, the composite Reliability and AVE values will be presented for all variables.

Table 3. Composite Reliability and Average Variance Extracted

\begin{tabular}{ccc}
\hline Composite Reliability & $\begin{array}{c}\text { Average Variance Extracted } \\
\text { (AVE) }\end{array}$ \\
\hline X1 & 0.923 & 0.705 \\
Y1 & 0.859 & 0.604 \\
Y2 & 0.866 & 0.684 \\
\hline
\end{tabular}

Based on table 3. it can be concluded that all constructs meet reliable criteria. This is indicated by the composite reliability value above 0.70 and AVE above 0.50 as recommended criteria.

\subsection{Testing of Structural Models (Inner Model)}

Testing of inner models or structural models is done to see the relationship between constructs, significance values and R-square of the research model. The structural model is evaluated using R-square for the dependent construct of the $t$ test and the significance of the structural path parameter coefficients.

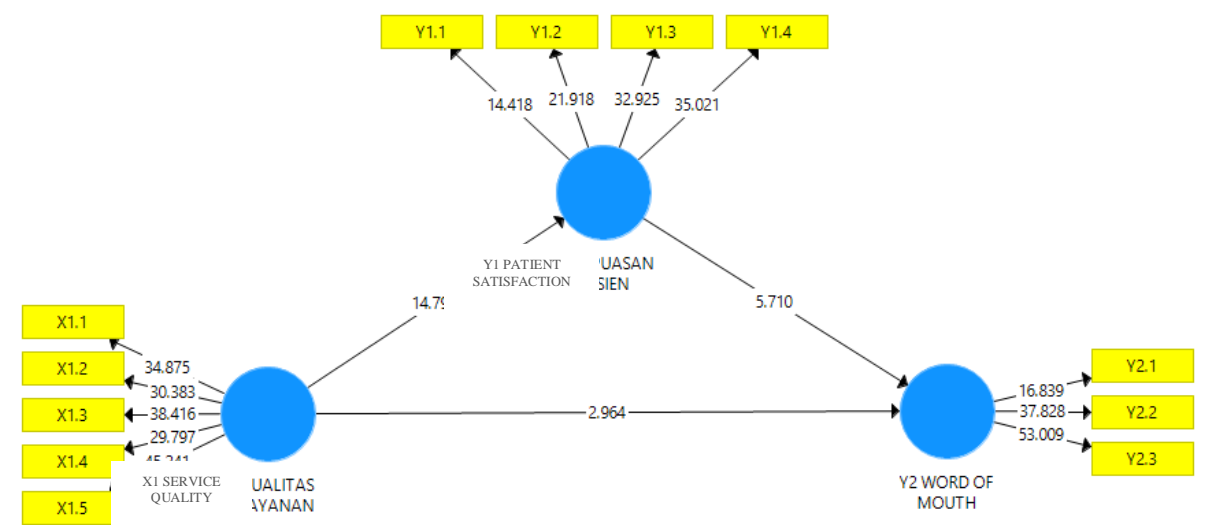

Fig. 1. Result of Model

In assessing the model with PLS it starts by looking at the R-square adjusted for each dependent latent variable.

Table 4. R Square Adjusted Variable R Square Adjusted

\begin{tabular}{cc}
\hline Variabel & R Square Adjusted \\
\hline Patient satisfaction (Y1) & $0.373(37,3 \%)$ \\
Word of Mouth (Y2) & $0.339(33,9 \%)$ \\
\hline
\end{tabular}

In this study consisted of 3 variables namely independent variables (free) as many as 1 variable namely Service 
Quality (X1), intervening variables as many as 1 variable namely Patient Satisfaction (Y1), and dependent variable as much as 1 namely Word of Mouth (Y2). Table 4.8 shows that the adjusted R Square value for the Patient Satisfaction variable (Y1) is 0.373 for thevariable Word of Mouth (Y2) obtained at 0.339 . These results indicate that $37.3 \%$ of the Patient Satisfaction variable (Y1) can be influenced by Service Quality (X1), while Word of Mouth (Y2). can be influenced by variables of Service Quality (X1), and Patient Satisfaction (Y1) with a value of 39.3\%.

\subsection{Hypothesis Testing}

Significance of the estimated parameters provides very useful information about the relationship between the research variables. The basis used in testing hypotheses is the value found in the output Path coefficent. The table provides estimated output for testing structural models.

Table 4. Value of the Path Coefficient

\begin{tabular}{lccccc}
\hline & $\begin{array}{c}\text { Original } \\
\text { Sample } \\
(\mathbf{O})\end{array}$ & $\begin{array}{c}\text { Sample } \\
\text { Mean } \\
(\mathbf{M})\end{array}$ & $\begin{array}{c}\text { Standard } \\
\text { Deviation } \\
(\text { STDEV) }\end{array}$ & $\begin{array}{c}\text { T Statistics } \\
(\mid \mathbf{O} / \text { STDEV })\end{array}$ & $\begin{array}{c}\mathbf{P} \\
\text { Values }\end{array}$ \\
\hline $\mathbf{X 1}$-> Y1 & 0.612 & 0.618 & 0.041 & 14.798 & 0.000 \\
$\mathbf{X 1}$-> Y2 & 0.209 & 0.209 & 0.070 & 2.964 & 0.002 \\
$\mathbf{Y 1}$-> Y2 & 0.436 & 0.439 & 0.076 & 5.710 & 0.000 \\
\hline
\end{tabular}

Hypothesis testing will be done by means of boostrapping to see $t$ statistics and p-values with a significant level of $5 \%$ (1.960). So that the acceptance criteria or rejection of the hypothesis is HA accepted and H0 rejected when $\mathrm{t}-$ statistics show $>1.960$, and to reject or accept the hypothesis using probability values, then Ha will be accepted if pvalue $<0.05$. The test results with bootstrapping from PLS analysis are as follows:

\subsection{Discussion}

\subsubsection{Effect of Service Quality (X1) on Patient Satisfaction (Y1)}

Based on the results of the analysis using smartPLS, it can be concluded that the construct of Service Quality has a significant effect on the construct of Patient Satisfaction. The results of testing the first hypothesis indicate that the effect of the Service Quality variable (X1) on Patient Satisfaction (Y1) shows a t value of 14.98 with a p-value of 0.000. This value is greater than $t$ table (1.960) and $p$-value is smaller than 0.05. This result means that Service Quality has a significant influence on Patient Satisfaction. This means that Hypothesis 1 is accepted. Thus, the H1 hypothesis in this study was accepted. This shows that good service quality will cause patients to be satisfied with the independent practice of Maria Surabaya midwives.

This is contrary to the research conducted by Pangandaheng (2015) which shows that service quality does not significantly influence customer satisfaction.

\subsubsection{Effect of Service Quality (X1) on Word of Mouth (Y2)}

Based on the results of the analysis using smartPLS, it can be concluded that the construct of service quality has a significant effect on the construct of Word of Mouth. The results of testing the second hypothesis show that the effect of the Service Quality variable (X1) on Word of Mouth (Y2) shows a t value of 2.964 with a p-value of 0.002 . This value is greater than $\mathrm{t}$ table (1.960) and p-value is smaller than 0.05 . This result means that Service Quality has a significant influence on Word of Mouth. This means that Hypothesis 2 is accepted. This shows that good service quality will encourage patients to do Word of Mouth in the independent practice of the Maria Surabaya midwife.

It is also supported by the research conducted by Anita \& Rahanatha (2015) that it is known that directly or indirectly the quality service has an effect on Word of Mouth. 


\subsubsection{Effect of Patient Satisfaction (Y1) on Word of Mouth}

Based on the results of the analysis using smartPLS, it can be concluded that the construct of patient satisfaction has a significant effect on the construct of Word of Mouth. The results of testing the third hypothesis indicate that the influence of the Patient Satisfaction variable (Y1) on Word of Mouth (Y2) shows a t value of 5.71 with a p-value of 0.000. This value is greater than t table (1.960) and p-value is smaller than 0.05. This result means that Patient Satisfaction has a significant influence on Word of Mouth. This means that Hypothesis 3 is accepted.

This is also supported by research conducted by Wijaya, Said \& Landra (2016). It is known that student satisfaction has a positive and significant effect on Word of Mouth.

\section{Conclusions}

Based on the problems that have been formulated, the results of the analysis and testing of hypotheses that have been carried out in the previous chapter, then the research can be concluded as follows:

1) Service Quality for Patient Satisfaction with a p-value of 0,000 and t value of 14,798 . This means that good service quality will cause patients to be satisfied with the independent practice of the Maria Surabaya midwife.

2) Service Quality for Word Of Mouth with a p-value of 0.002 and a t value of 2.964. Based on the results of data processing, this means that good service quality will encourage patients to do Word of Mouth in the independent practice of Maria Surabaya midwife

3) Patient Satisfaction with Word Of Mouth with a p-value of 0,000 and a t value of 5.71. This means that Patient Satisfaction will cause patients to do Word of Mouth in the independent practice of Maria Surabaya midwives.

\section{References}

Anita, Ni Luh Nyoman Y; Rahanatha, GB (2018). Effect of Service Quality on WOM Through Satisfaction at PT. Sarana Dewata Courier. 1(2), 83-101.

Kasmir. (2005). Customer Service Ethics. RajaGrafindo Persada. Jakarta.

Khasali, R. (2003). Advertising and Application Management in Indonesia, Eleventh Edition. Pustaka Utama Grafika, Jakarta.

Kotler, P. \& Keller, K. L., (2016). MarketingManagement, $15^{\text {th }}$ Edition.Prentice Hall International, New Jersey.

Lovelock, C., Wirtz, J., \& Mussry, J. (2012). Marketing of Human Services, Technology, Strategy : Indonesian Perspective. Erlangga Publisher, Jakarta.

Lovelock, C., Patterson, P. G. \& Wirtz, J. (2014). Services Marketing. Pearson, Australia.

Malhotra, N. K. (2009). Applied Market Research Approach. Fourth edition. Volume 2. PT.Index Gramedia Group

Giel, N. K. (1995). "Customer Satisfaction Measurement and Management", Cincinnati, Ohio: Thomas Executive Press.

Pangandaheng, F. (2013). The Effect of Service Quality and Company Image on Customer Satisfaction and Its Impact on Customer Loyalty at PT. Hadji Kalla Palu. Journal of Business and Management Sciences, 3(2), 51-67.

Sanjuq, G. (2014). The Impact of Service Quality Delivery on Customer Satisfaction in the Banking Sector in Riyadh, Saudi Arabia. International Journal of Business Administration, 5(4), 77-84. https://doi.org/10.5430/ijba.v5n4p77

Sugiyono. (2010). Quantitative, Qualitative Research and R \& D Methods. Alfabeta. Bandung. 
Sholeha, L., Djaja, S., \& Widodo, J. (2018). The Influence of Service Quality on Customer Satisfaction in Ahass Sumber Jaya Maha Sakti, Rogojampi District, Banyuwangi Regency. JOURNAL OF ECONOMIC EDUCATION: Scientific Journal of Education, Economics and Social Sciences, 12(1), 15. https://doi.org/10.19184/jpe.v12i1.6465

Suryawijaya, N., Said, S., \& Landra , N. (2016). The Influence of Academic Service Quality and Price (Cost of Education) on Word of Mouth Through Student Satisfaction As Intervening Variables (Study on LPK Bali Hospitality) INTERVENING (STUDY ON BALI HOSPITALITY SCHOOL OF SCHOOL). Hospitality Management Scientific Journal, 6(2), 101-114.

Tjiptono, F. \& Chandra, G. (2011). Service, Quality \& Satisfaction, Issue 3. Andi Publisher, Yogyakarta.

Tjiptono, F. (2014). Service, Quality \& Satisfaction, Issue 3. Publishers Andi, Yogyakarta

Tuju, RE, \& Loindong, S. (2018). The Effect of Service Quality and Yamaha Motorcycle Products on Customer Satisfaction Pt. Hasjrat Abadi in Manado. EMBA Journal, 6(3), 1798-1807. Zeithaml, Valarie A and Mary Jo Bitner. 2000. Service Marketing. Singapore: Mc Graw-Hill Companies Inc .: 3-287. 